\title{
Sulphonylureas in Vitro Do Not Alter Insulin Binding or Insulin Effect on Amino Acid Transport in Rat Hepatocytes
}

\author{
J. Dolais-Kitabgi, F. Alengrin and P. Freychet
}

Department of Research on Polypeptide Hormones and Endocrine Physiopathology (INSERM U 145)

and Laboratory of Experimental Medicine, Faculty of Medicine, University of Nice, Nice, France

Summary. The effects of four sulphonylureas (gliclazide, gli-
benclamide, chlorpropamide and glipizide) on insulin bind-
ing and insulin action were studied in vitro using primary cul-
tured rat hepatocytes. Cells were cultured for $20 \mathrm{~h}$ in the ab-
sence or presence of the sulphonylurea. The binding of insulin
to rat hepatocyte monolayers was not altered in cells previous-
ly exposed to gliclazide at $0.7,7.0$ or $70 \mu \mathrm{g} / \mathrm{ml}$; and to gliben-
clamide, chlorpropamide, or glipizide at $0.1,1.0$ and $10 \mu \mathrm{g} /$
ml. Insulin-induced down regulation was not affected by a si-
multaneous exposure of hepatocyte monolayers to any of the four agents. The stimulatory effect of insulin on $\alpha$-aminoisobutyric acid uptake by the cells was not modified following exposure to the drugs. These studies indicate that the sulphonylureas tested do not have a direct effect on insulin receptors in hepatocytes; and that, in vitro, they do not alter the post-receptor events involved in the insulin-induced stimulation of amino acid transport in these cells.

Key words: Insulin receptors, aminoacid transport, primary cultures of hepatocytes, sulphonylureas.
There is some evidence that part of the therapeutic effects of sulphonylureas on glucose metabolism is due to an extrapancreatic action of the drugs, but the mechanism involved in this action is unclear at present. It has been suggested that sulphonylureas, administered in vivo [1-4] or employed in vitro [5], may enhance insulin action through increasing the hormone binding to its receptors; in these studies, the possible consequence of this increase in binding on the hormone biological function was not specifically investigated. It has, however, been reported recently that insulin effect is enhanced while insulin binding remains unaltered following exposure of adipose tissue to tolazamide in vitro [6]. Indeed, a causal implication of insulin receptors in any extrapancreatic effect of sulphonylureas remains to be demonstrated.

The present study was designed to seek a direct effect of sulphonylureas on the liver in vitro. The effects of gliclazide, glibenclamide, glipizide and chlorpropamide on insulin binding and insulin effect on amino acid transport in primary cultured rat hepatocytes were investigated.

\section{Materials and Methods}

\section{Chemicals}

$\alpha$-Amino $\left(1-{ }^{14} \mathrm{C}\right)$ isobutyric acid (specific activity, $60 \mathrm{Ci} / \mathrm{mol}$ ), and $\left({ }^{3} \mathrm{H}\right)$ inulin (specific activity, $500 \mathrm{Ci} / \mathrm{mol}$ ) were purchased from the Radiochemical Centre, Amersham, Bucks, UK; $\mathrm{Na}^{125} \mathrm{I}$ was obtained from the Commissariat à l'Energie Atomique, Saclay, France. Porcine monocomponent insulin was a gift from the Novo Research Institute, Copenhagen, Denmark and from Novo France (Paris). Waymouth's MB 752/1 medium, penicillin, streptomycin and fetal calf serum were from Grand Island Biological Company, Grand Island, New York; defatted bovine serum albumin (BSA, Fraction V) was from Sigma Chemicals, St. Louis, Missouri. Gliclazide was provided by Dr. C. Nathan, Laboratoires Servier, Paris. Chlorpropamide and glipizide were obtained from Laboratoires Pfizer, Orsay, France. Glibenclamide was from Laboratoires Hoechst, Paris. All other reagents were of the best grade commercially available.

\section{Primary Cultured Hepatocytes and Incubation Conditions}

All experiments were performed with primary cultures of adult rat hepatocytes, prepared as previously described [7], except that cells were plated at a concentration of $1 \times 10^{6} / \mathrm{ml}$. After $4 \mathrm{~h}$ at $37^{\circ} \mathrm{C}$ in the presence of $10 \%$ fetal calf serum (attachment period), hepatocyte monolayers were incubated for $20 \mathrm{~h}$ in serum-free Waymouth's medium in the presence or absence of insulin at $3 \mu \mathrm{mol} / 1$ and/or the sulphonylurea at varying concentrations. The medium was changed twice during the 20 -h incubation period, with insulin and/or the sulphonylurea being reintroduced with fresh medium at each change. In some experiments, the level of gliclazide in the incubation medium at each medium change was determined by high performance liquid chromatography and was found to represent $50 \%-80 \%$ of the initial amount of the drug. After the final removal of the medium at the end of the 20 -h incubation period, hepatocyte monolayers were extensively washed in insulin-free or drug-free medium at $37^{\circ} \mathrm{C}$ before the determination of insulin binding and transport studies. The washing procedure, which consisted of three successive incubations (each with a duration of $25 \mathrm{~min}$ ) in insulin-free medium at $37^{\circ} \mathrm{C}$, was designed to dissociate receptor-bound insulin in hepatocyte monolayers previously exposed to the hormone for $20 \mathrm{~h}$. This procedure was observed to 


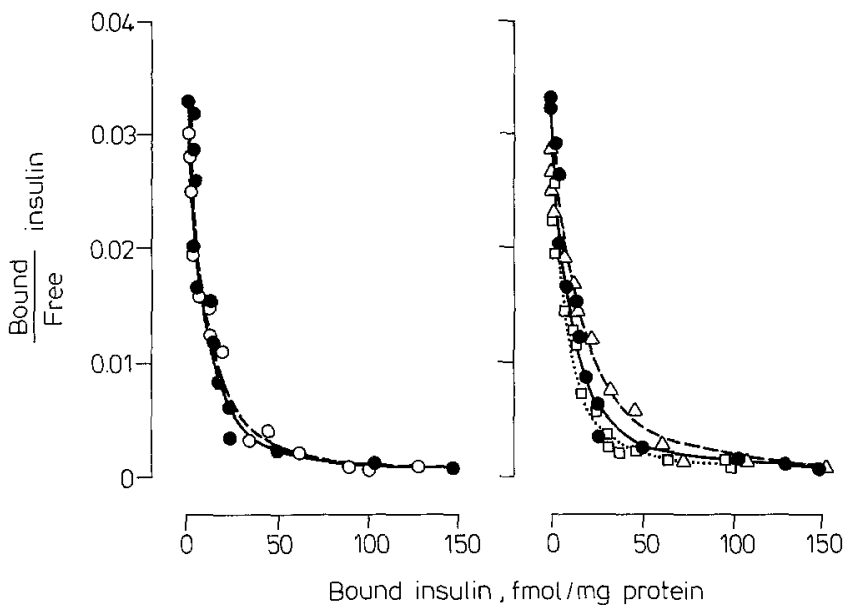

Fig. 1. Scatchard analysis of insulin binding to hepatocyte monolayers following exposure for $20 \mathrm{~h}$ to gliclazide. Insulin binding was measured at $37^{\circ} \mathrm{C}$ under steady state conditions as described in Materials and Methods. The data correspond to a representative experiment; each point is the mean of triplicate determinations. Key: - control, $\bigcirc \cdots . . .0$ gliclazide $(0.7 \mu \mathrm{g} / \mathrm{ml}) \square \cdots \cdots \square$ gliclazide $(7.0 \mu \mathrm{g} / \mathrm{ml}) \Delta \cdots \Delta$ gliclazide $(70 \mu \mathrm{g} / \mathrm{ml})$

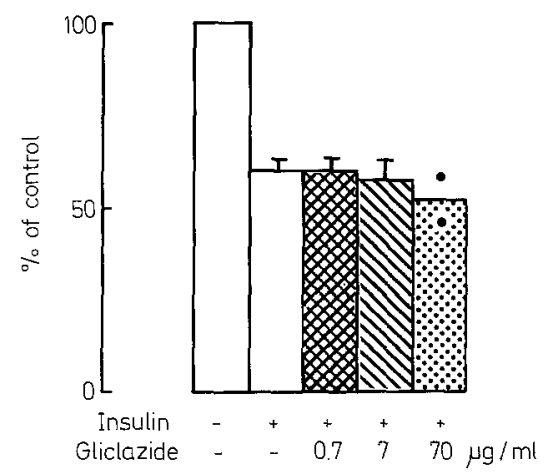

Fig. 2. Effect of gliclazide on insulin-induced down regulation in hepatocyte monolayers. Hepatocytes were incubated for $20 \mathrm{~h}$ without or with insulin at $3 \mathrm{umol} / 1 \mathrm{in}$ the absence or presence of gliclazide at 0.7 , 7.0 and $70 \mu \mathrm{g} / \mathrm{mi}$. Control cells were incubated under the same conditions, except that insulin was added $10 \mathrm{~min}$ before the washing procedure, as described in Materials and Methods. Insulin binding was measured at $37^{\circ} \mathrm{C}\left(1 \mathrm{~h}\right.$-incubation) with ${ }^{125} \mathrm{I}$-insulin $(0.3 \mathrm{ng} / \mathrm{ml})$ and data were corrected for non-specific binding. Results are expressed as a percentage of respective controls, and represent the mean $\pm S E M$ of three to four separate experiments except for gliclazide at $70 \mu \mathrm{g} / \mathrm{ml}$ where each dot represents separate experiments with each point run in quadruplicate. SEM of replicates ranged from 2 to $5 \%$ of each value

cause the removal of about $90 \%$ of cell-associated insulin. Determination of insulin concentration in the medium by radioimmunoassays and rebinding studies indicated that $30 \%-70 \%$ of the hormone was intact at the end of each incubation period.

\section{Insulin Binding Studies}

Insulin was iodinated to a specific activity of $200-250 \mu \mathrm{Ci} / \mu \mathrm{g}$ using a modification [referred to as the second modification in 8] of the chloramine $\mathrm{T}$ method; ${ }^{125} \mathrm{I}$-insulin was purified by gel filtration (Sephadex G50 Fine). Under our conditions of iodination the binding properties of radiolabelled insulin were indistinguishable from those of A 14 monoiodinated insulin [9]. Binding assays were performed as previ- ously described $[7,10]$. Briefly, after the washing procedure hepatocyte monolayers were resuspended in Krebs-Ringer bicarbonate (KRB) buffer containing $1 \%$ bovine serum albumin (BSA), bacitracin $(0.8 \mathrm{mg} / \mathrm{ml})$ and gentamicin $(50 \mu \mathrm{g} / \mathrm{ml})$, and incubated for $1 \mathrm{~h}$ at $37^{\circ} \mathrm{C}$ with $0.3 \mathrm{ng} / \mathrm{ml}$ of ${ }^{125} \mathrm{I}$-insulin in the absence or presence of increasing concentrations of unlabelled hormone; previous studies have shown that under these conditions binding reaches a steady state [7]. Unless indicated otherwise, binding assays were performed in the absence of the sulphonylurea. In order to account for the residual receptor occupancy that occurs despite the extensive washing procedure in hepatocyte monolayers previously exposed to insulin at $3 \mu \mathrm{mol} / 1$, control experiments were performed in which cells were 'acutely' exposed to the hormone $(3 \mu \mathrm{mol} / 1)$ for $10 \mathrm{~min}$ before the washing steps. All binding data have been corrected for non-specific binding as previously described [7], and expressed per mg of cell protein. Non-specific binding represented $10 \%-20 \%$ of total insulin binding.

\section{Amino Acid Transport Studies}

The effect of insulin on amino acid transport in hepatocyte monolayers was investigated by use of $\alpha$-aminoisobutyric acid (AIB), a nonmetabolisable analogue of alanine. After the washing procedure that followed the 20 -h incubation period, monolayers were incubated in the same buffer as that described above for binding studies, in the absence or presence of various insulin concentrations. After $3 \mathrm{~h}$ of incubation at $37^{\circ} \mathrm{C}$, transport assays were performed as previously described [7] by adding $\left({ }^{14} \mathrm{C}\right) \mathrm{AIB}$ and $\left({ }^{3} \mathrm{H}\right)$ inulin for $30 \mathrm{~min}$. All transport data have been corrected for extracellular trapping (assessed by $\left({ }^{3} \mathrm{H}\right)$ inulin), and expressed per $\mathrm{mg}$ of cell protein. In some experiments, the effect of insulin on AIB uptake was studied in the presence of the sulphonylurea.

\section{Statistical Analysis}

Statistical analysis was performed using the Student's t-test for unpaired comparisons.

\section{Results}

\section{Insulin Binding}

The binding of insulin to hepatocyte monolayers was measured under steady state conditions at $37^{\circ} \mathrm{C}$ using ${ }^{125} \mathrm{I}$-insulin and varying concentrations of unlabelled insulin. Scatchard analysis (Fig. 1) of these data revealed no detectable change in receptor number or affinity in hepatocytes previously exposed to gliclazide $(0.7 ; 7.0$; and $70 \mu \mathrm{g} / \mathrm{ml}$ ) for $20 \mathrm{~h}$, compared with controls. Results were the same when the sulphonylurea remained present throughout the completion of the binding assay, or when the drug was present only during the assay itself.

In order to investigate a possible effect of gliclazide on the insulin-induced loss of insulin binding ("down regulation'), hepatocyte monolayers were first exposed to insulin $(3 \mu \mathrm{mol} / 1$, i. e, $400 \mathrm{mU} / 1)$ without or with gliclazide $(0.7 ; 7.0$; and $70 \mu \mathrm{g} / \mathrm{ml})$ for $20 \mathrm{~h}$ at $37^{\circ} \mathrm{C}$. As shown in Figure 2, a previous exposure of the cells to insulin reduced subsequent insulin binding by about $45 \%$ compared with controls. At all three concentrations tested, gliclazide failed to affect the insulin-induced loss of insulin binding (Fig. 2).

The effect of other sulphonylureas on insulin binding was also tested by incubating primary cultured hep- 


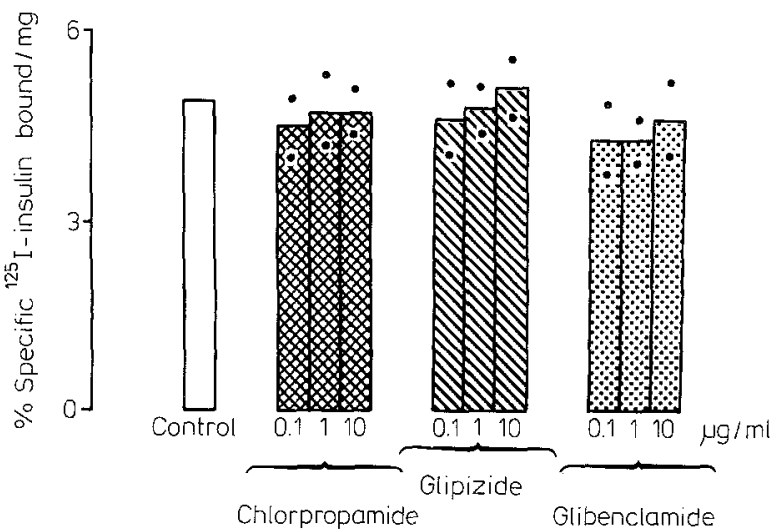

Fig.3. Effects of chlorpropamide, glipizide and glibenclamide on insulin binding to hepatocyte monolayers. Cells were exposed for $20 \mathrm{~h}$ to the sulphonylurea at $0.1,1.0$ and $10 \mu \mathrm{g} / \mathrm{ml}$, and the specific binding of ${ }^{125} \mathrm{I}$-insulin $(0.3 \mathrm{ng} / \mathrm{ml})$ was measured $\left(1 \mathrm{~h}\right.$ at $\left.37^{\circ} \mathrm{C}\right)$. Data are the mean of two representative experiments where each point was determined in quadruplicate. Within each experiment SEM of replicates ranged from 2 to $5 \%$ of each value

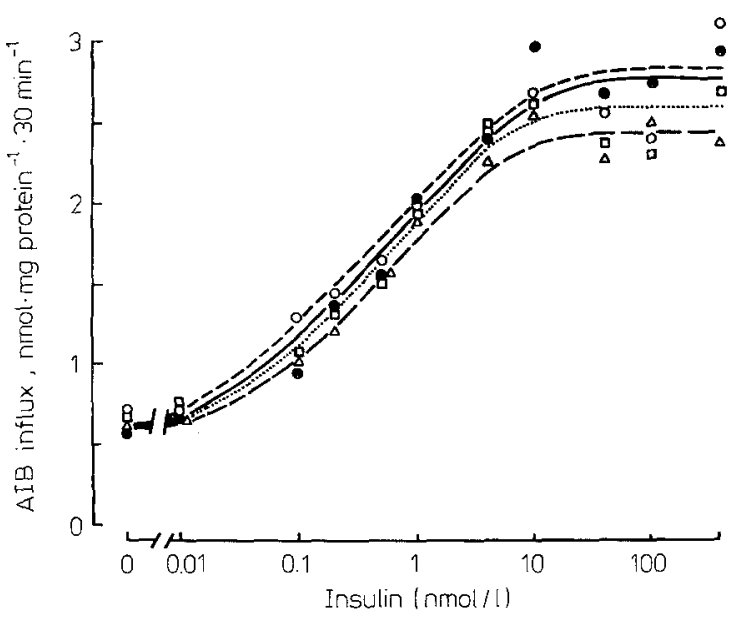

Fig.4. Dose-response curves of insulin stimulation of $\alpha$-amino isobutyric acid (AIB) uptake in hepatocyte monolayers following exposure to gliclazide. After exposure to gliclazide at $0.7,7.0$ and $70 \mu \mathrm{g} / \mathrm{ml}$ for $20 \mathrm{~h}$, cells were incubated for $3 \mathrm{~h}$ in the presence of various concentrations of insulin. The uptake of AIB $(0.1 \mathrm{mmol} / \mathrm{l})$ was then measured as described under Materials and Methods. Results have been expressed as nmol of AIB taken up per mg of cell protein over $30 \mathrm{~min}$. Each value is the mean of two separate experiments where each point was run in triplicate. Key: - control, $\bigcirc-.-0$ gliclazide $(0.7 \mu \mathrm{g} / \mathrm{ml}), \quad \square \cdots \cdots \square$ gliclazide $(7.0 \mu \mathrm{g} / \mathrm{ml}), \Delta-\cdots \Delta$ gliclazide $(70 \mu \mathrm{g} / \mathrm{ml})$

Table 1. Effect of glipizide, glibenclamide and chlorpropamide on insulin-induced 'down regulation'

\begin{tabular}{|c|c|c|}
\hline \multirow{2}{*}{$\begin{array}{l}\text { Sulphonylurea } \\
\text { (at } 10 \mu \mathrm{g} / \mathrm{ml} \text { ) }\end{array}$} & \multicolumn{2}{|c|}{$\%{ }^{125} \mathrm{I}$-insulin specifically bound $\mathrm{mg}$ protein } \\
\hline & Control cells & Insulin-treated cells \\
\hline None & $6.3 \pm 0.1$ & $3.0 \pm 0.2$ \\
\hline Glipizide & $6.1 \pm 0.1$ & $3.0 \pm 0.1$ \\
\hline Glibenclamide & $6.6 \pm 0.2$ & $3.1 \pm 0.2$ \\
\hline Chlorpropamide & $6.5 \pm 0.2$ & $3.0 \pm 0.1$ \\
\hline
\end{tabular}

Each value is the mean \pm SEM of four determinations
Table 2. Effect of glipizide, glibenclamide and chlorpropamide on insulin stimulation of AIB transport

\begin{tabular}{|c|c|c|c|c|}
\hline & \multicolumn{4}{|c|}{$\begin{array}{l}\alpha \text {-aminoisobutyric acid uptake }(\mathrm{nmol} \cdot \mathrm{mg} \\
\left.\text { protein }^{-1} \cdot 30 \mathrm{~min}^{-1}\right)\end{array}$} \\
\hline & & Basal & $\begin{array}{l}\text { Insulin } \\
(100 \mathrm{nmol} / \mathrm{l})\end{array}$ & $\begin{array}{l}\text { Incre- } \\
\text { ment }\end{array}$ \\
\hline \multicolumn{5}{|l|}{ Experiment 1} \\
\hline Control & & $0.50 \pm 0.04$ & $1.56 \pm 0.07$ & 1.06 \\
\hline Glipizide & 0.1 & $0.61 \pm 0.02$ & $1.61 \pm 0.16$ & 1.00 \\
\hline \multirow[t]{2}{*}{$(\mu \mathrm{g} / \mathrm{ml})$} & 1.0 & $0.68 \pm 0.05$ & $1.64 \pm 0.05$ & 0.96 \\
\hline & 10 & $0.69 \pm 0.06$ & $1.74 \pm 0.06$ & 1.05 \\
\hline \multicolumn{5}{|l|}{ Experiment 2} \\
\hline Control & & $0.30 \pm 0.05$ & $0.94 \pm 0.05$ & 0.64 \\
\hline Glibenclamide & 0.1 & $0.22 \pm 0.01$ & $0.94 \pm 0.02$ & 0.72 \\
\hline \multirow[t]{2}{*}{$(\mathrm{ug} / \mathrm{ml})$} & 1.0 & $0.40 \pm 0.02$ & $1.10 \pm 0.09$ & 0.70 \\
\hline & 10 & $0.21 \pm 0.01$ & $0.90 \pm 0.08$ & 0.69 \\
\hline \multicolumn{5}{|l|}{ Experiment 3} \\
\hline Control & & $0.44 \pm 0.04$ & $1.25 \pm 0.06$ & 0.81 \\
\hline \multirow[t]{2}{*}{ Ethanol } & $0.02 \%$ & $0.34 \pm 0.03$ & $1.28 \pm 0.08$ & 0.94 \\
\hline & $0.25 \%$ & $0.34 \pm 0.03$ & $1.65 \pm 0.09$ & 1.31 \\
\hline \multirow{3}{*}{$\begin{array}{l}\text { Chlorpropamide } \\
(\mu \mathrm{g} / \mathrm{ml})\end{array}$} & 0.1 & $0.42 \pm 0.02$ & $1.41 \pm 0.07$ & 0.99 \\
\hline & 1,0 & $0.43 \pm 0.04$ & $1.58 \pm 0.04$ & 1.15 \\
\hline & 10 & $0.41 \pm 0.04$ & $1.50 \pm 0.09$ & 1.09 \\
\hline
\end{tabular}

Cells were incubated for $20 \mathrm{~h}$ in the absence or presence of the sulphonylurea, and insulin was added for 3 additional hours. The uptake of $\alpha$-aminoisobutyric acid was measured at $0.1 \mathrm{mmol} / \mathrm{l}$ as described under Materials and Methods. Results are expressed as mean \pm SEM of three determinations. In experiment 3 , the small effect observed at 1 and $10 \mu \mathrm{g} / \mathrm{ml}$ was similar to that observed with the diluent alone, i.e., 0.02 and $0.25 \%$ ethanol, respectively

atocytes with chlorpropamide, glipizide, or glibenclamide (glyburide), for $20 \mathrm{~h}$ before the binding assay. Again, insulin binding was not affected by this previous exposure of the cells to any of these sulphonylureas (Fig. 3). As observed with gliclazide, the insulin-induced loss of insulin binding was not altered by glipizide, chlorpropamide, or glibenclamide at $10 \mu \mathrm{g} / \mathrm{ml}$ (Table 1).

\section{Amino Acid Transport}

The effect of insulin on amino acid transport was investigated in hepatocyte monolayers previously exposed for $20 \mathrm{~h}$ to gliclazide at $0.7 ; 7.0 ;$ and $70 \mu \mathrm{g} / \mathrm{ml}$. Maximal effects of insulin (hormone at $100 \mathrm{nmol} / 1$ ) were not statistically different $(p>0.05, n=4)$ in control cells and in gliclazide treated hepatocytes. As depicted in Figure 4, dose responses of the hormone's effect on AIB influx in cells pre-treated with gliclazide were similar to that observed in controls. In all conditions tested, the halfmaximal response was elicited by insulin at about $0.5 \mathrm{nmol} / 1$. It was also observed that the presence of gliclazide with insulin during the $3 \mathrm{~h}$ incubation preceding the assay of AIB transport did not alter the stimulation effect of the hormone on AIB influx.

In similar manner, pre-treating hepatocyte monolayers with glipizide, glibenclamide, or chlorpropamide $(0.1 ; 1.0 ;$ and $10 \mu \mathrm{g} / \mathrm{ml})$ for $20 \mathrm{~h}$ did not affect the sub- 
sequent stimulation of AIB influx by a maximally effective concentration $(100 \mathrm{nmol} / \mathrm{l})$ of insulin (Table 2$)$. Similar observations were made when a submaximally stimulating concentration $(0.4 \mathrm{nmol} / 1)$ of insulin was employed.

\section{Discussion}

The present study has revealed that the number and the affinity of insulin receptors in primary cultured rat hepatocytes are not affected following a $20 \mathrm{~h}$ exposure of these cells to the sulphonylureas gliclazide, glibenclamide, chlorpropamide, and glipizide. We have also shown that these sulphonylureas do not interfere with the ability of insulin to regulate its own receptor. Our findings are in agreement with recent reports by Maloff and Lockwood [6] in rat adipose tissue, and by Vigneri [12] in three human cell lines and H35 rat hepatoma. These and our results are in contrast with the study by Prince and Olefsky [5] who reported a slight increase (about $20 \%$ ) in insulin binding and a partial inhibition of insulin-induced down regulation in cultured human fibroblasts following exposure to glyburide (i.e. glibenclamide). We have no explanation for this discrepancy, except that differences may exist among tissues regarding the action of sulphonylureas. Thus, despite the fact that insulin receptors in liver membranes increase following reatment of the animal with a sulphonylurea in vivo $[2,3]$, we have been unable to demonstrate a direct effect of four different sulphonylureas on insulin binding in hepatocytes, suggesting that the increase in hepatic insulin receptors observed after administration in vivo is due to a secondary rather than a primary effect of the drugs.

The present study was also designed to search for a direct, albeit post-receptor, effect of sulphonylureas on insulin action in liver. Our results indicate that the stimulatory effect of insulin on amino acid influx in hepatocytes is not enhanced by the previous exposure of the cells to a broad range of concentrations of gliclazide, glibenclamide, glipizide, or chlorpropamide. These results are at variance with studies in vivo which have shown that administration of tolbutamide [13], glipizide [14, 15], or glibenclamide [4], enhances insulin action but, as discussed above regarding binding data, such effects may be secondary rather than primary. Our results also differ from those reported by Blumenthal [16] using the isolated perfused liver, and from the observation by Maloff and Lockwood [6] who reported that tolazamide in vitro enhances the insulin stimulation of hexose transport in adipose tissue. Since, we investigated the effects of four sulphonylureas on amino acid transport in hepatocytes, whereas Maloff and Lockwood examined the effect of another sulphonylurea on glucose transport in adipocytes, it is difficult to compare the two studies. Moreover, sulphonylureas may specifically alter the action of insulin on carbohy- drate metabolism by a post-receptor effect, without affecting other biological responses.

Acknowledgements. We thank C. Fenot, G.Visciano and N.Gautier for expert technical assistance; L. Capolongo, J. Duch and A. Rainaud for excellent secretarial assistance. We thank Dr. G. Damien of Technologie Servier, France, for the determination of gliclazide levels. This work was supported in part by a grant from Laboratoires Servier, Paris, France.

\section{References}

1. Olefsky JM, Reaven GM (1976) Effects of sulfonylurea therapy on insulin binding to mononuclear leukocytes of diabetic patients. Am J Med 60: 89-95

2. Feinglos MN, Lebovitz HE (1978) Sulfonylureas increase the number of insulin receptors. Nature 276: 184-185

3. Bachmann W, Bottger I, Haslbeck M, Mehnert H (1979) Extrapancreatic action of sulfonylureas: effect of gliquidone on insulin and glucagon binding to rat liver plasma membranes. Eur $\mathrm{J}$ Clin Invest 9: 411-415

4. Beck-Nielsen H, Pedersen O, Lindskov MO (1979) Increased insulin sensitivity and cellular binding in obese diabetics following treatment with glibenclamide. Acta Endocrinol 90:451-462

5. Prince MJ, Olefsky JM (1980) Direct in vitro effect of a sulfonylurea to increase human fibroblast insulin receptors. J Clin Invest 66: $608-611$

6. Maloff BL, Lockwood DH (1981) In vitro effects of a sulfonylurea on insulin action in adipocytes. J Clin Invest 68: 85-90

7. Morin O, Fehlmann M, Freychet P (1982) Binding and action of insulin and glucagon in monolayer cultures and fresh suspensions of rat hepatocytes. Mol Cell Endocrinol 25:339-352

8. Freychet P (1976) Insulin receptors. In: Blecher M (ed) Methods in receptor research, Part II. Marcel Dekker, New York, Basel, pp 385-428

9. Fehlmann M, Le Marchand-Brustel Y, Dolais-Kitabgi J, Morin O, Freychet P (1981) Biological activity and receptor binding properties of biosynthetic human insulin in isolated rat hepatocytes and mouse soleus muscle in vitro. Diabetes Care 4:223-227

10. Dolais-Kitabgi J, Checler F, Rey JF, Morin O, Freychet P (1981) Insulin stimulation of amino acid transport in primary cultured rat hepatocytes varies in direct proportion to insulin binding. FEBS Lett 128: 321-324

11. Fehlmann M, Morin O, Kitabgi P, Freychet P (1981) Insulin and glucagon receptors of isolated rat hepatocytes: comparison between hormone binding and amino acid transport stimulation. Endoctinology 109: 253-261

12. Vigneri $R$ (1982) Comparison of the in vitro effect of biguanides and sulfonylureas on insulin binding to its receptor in target cells. J Cell Endocrinol Metab 54: 95-100

13. Colwell AR (1964) Potentiation of insulin action on the liver by tolbutamide. Metabolism 13:1310-1317

14. Lebovitz HE, Feinglos MN, Bucholtz HK, Lebovitz FL (1977) Potentiation of insulin action: a probable mechanism for the antidiabetic action of sulfonylurea drugs. J Clin Endocrinol Metab 45: 601-604

15. Putnam WS, Andersen DK, Jones RS, Lebovitz AF (1981) Selective potentiation of insulin mediated glucose disposal in normal dogs by the sulfonylurea glipizide. J Clin Invest 4: 1016-1023

16. Blumenthal SA (1977) Potentiation of the hepatic action of insulin by chlorpropamide. Diabetes $26: 485-489$

Received: 27 August 1982

and in revised form: 14 December 1982

Dr. J. Dolais-Kitabgi

INSERM U 145

Faculté de Médecine Pasteur

Avenue de Vallombrose

F-06034 Nice Cédex, France 